\title{
高電界下での表面過程
}

\author{
渡 辺一之 \\ 東京理科大学理学部 正162 東京都新宿区神楽坂 1-3 \\ (1992 年 12 月 4 日受理)
}

\section{Surface Processes in High Electric Fields}

\author{
Kazuyuki Watanabe \\ Department of Physics, Faculty of Science, Science University of Tokyo \\ 1-3 Kagurazaka, Shinjuku, Tokyo 162
}

(Received December 4, 1992)

\begin{abstract}
固体表面の精密な組成分析や構造分析, またその電子状態の解析のための実験法にはしばしば外部静電界 が用いられる。原子スケール制御といった最近の新技術においてあ電界は欠かせない。では，その原子ス ケール，すなわちオングストロームの表面世界で電界はどのような役割を担うのであろうか？ 従来の経験 的手法にたよらず，第一原理電子論の方法を用いて電界効果の解析を試みた。固体表面に強電界 $(\sim 1 \mathrm{~V} / \AA)$ が印加された場合に表面電荷分布，原子配置がごのような変更を受けるかを探るために，重要な物質面であ る $\mathrm{Si}(100)$ 表面を調べた。表面緩和の特徵は, 電界の方向により異なり, 電荷分布の変形は表面で突出した 原子近傍で顕著である。表面原子が電界蒸発する際の原子位置と電界強度の関係を求め, 蒸発機構の予測を 行った。
\end{abstract}

\section{1.はじめに}

昔から，電界（あるいは電圧）は系の電気的性質，ミ クロにはその電子状態を変えるために使われてきた。物 質に電流を流すことからはじまり, 電気分解, 原子の イオン化, 絶縁体中の電子トンネリング, など数多くの 态用がある。最近, 半導体デバイスの超微細化に触発さ れ，“原子単位制御”関連した研究が注目を集めてき ているが, そこでも電界は重要な役割を演じる。

走査型トンネル顕微鏡 (STM) 針を用いて, Ni 表面 飞 Xe 原子 35 個からなる “IBM” の原子文字を作りあ げた Eigler の仕事”衝撃的であった。その後, Si 表 面の原子単位加工 ${ }^{2)}$, 原子スイッチ3) など単一原子制御 が STM を舞台に実現しつつある。

STM では, 電界・電流のある状況で表面原子が STM 針と相互作用する。したがって，原子の配置を制御する ためには，表面束縛ポテンシャルの形状が，STM 針と の距離と電界の強さによってどう変形するかを知らなけ ればならない。電界が表面原子近くの電子状態を大きく 変えることは, STM が発明される 20 年以上屯前に電界
イオン顕微鏡 $(\mathrm{FIM})^{4)}$ において認識されていた。特に電 界脱離・蒸発5) を果しているととを示すよい例である。乙れらの現象に 対する物理的解釈は現象論によってなされてきた。すな わち, 電界がつくる表面束縛ポテンシャルは古典電磁気 学の範囲で経験的に導入されたものであった。しかし， 原子スケールでの表面素過程を理解するには，あはや経 験論は不適切であり, 特に表面新物性を予測するという 観点からも, 量子論による電界効果の微視的解析が必須 となる。

こてでは, 量子論的 (第一原理) 分子動力学法6) とい う安定な原子配置と電子状態を同時に決定する数値解析 法を用いて, 電界が加わった $\mathrm{Si}(100)$ 表面の原子配置, 表面電荷分布を調べたので紹介する。また, Si 原子が 電界蒸発するときの原子位置とそのときの電界強度の関 係を求めるととができたので, 蒸発機構についても考え てみたい。

\section{2. 表面電界}

具体的な問題に入る前に, 表面電界の基本的なふるま 

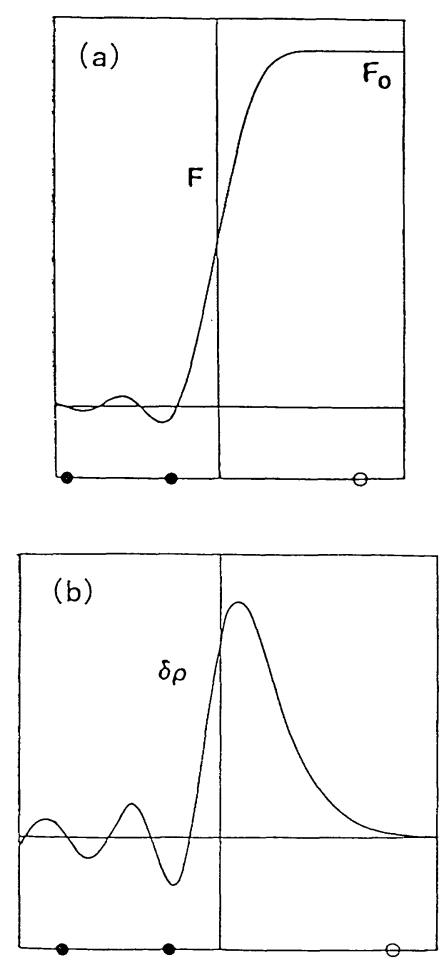

図 1 ジェリウム表面における電界

左半分がジェリウム, 右半分が真空。黒丸，白丸 はそれぞれ固体表面原子，吸着原子のおおよその 位置

（a）電界 $F_{0}$ を加えたときのジェリウム表面へ の電界の進入の様子

（b）負電界（ジェリウムが負の電位）を加えた ときの表面電荷分布の変形部分 ${ }^{8)}$

いについて見てみよう。現実の結晶は電子と正イオンか らなるが, 正イオン部分を空間的に均一にならし, 電子 状態だけを正確に取り扱う方法にジェリウムモデルがあ る。密度汎関数法（DF）（詳しくは文献7）を参照された い)といういわゆるバンド計算の理論的手法を, 外部電 界がかけられたジェリウム表面に適用して得られた結果 の特徵を図 $1^{8)}$ に示す。図の左半分が固体で右半分が 真空である。図1(a) には外からかけた電界の固体への 侵入の様子が描かれている。表面電子の遮蔽効果によっ て, 電界は表面から数 $\AA$ のあたりでゼロに近くなる。 古典論によると, 真空で一定な電界は固体内に入ると不 連続的にゼロになることを思い起てされたい。図 1(b) には負の電界（表面が負の電位）が加わったときの表面 電荷分布の変形部分が描かれている。真空部分にしみだ している様子がわかるであろう。逆方向の電界をかける と，固体内部に電荷が押し込まれるように変形する。実 質的な表面の位置はジェリウムの境界とは異なり, 表面

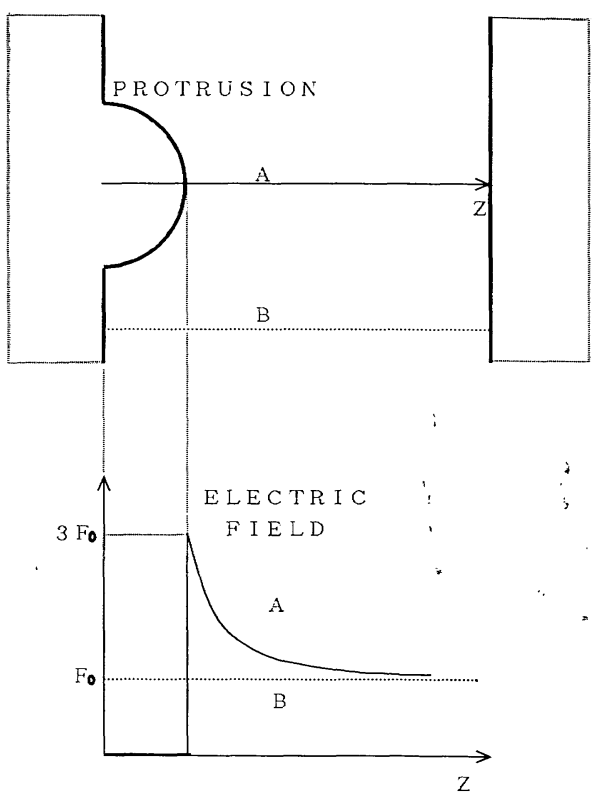

図 2 半球突起のある表面での電界 半球突起直上で，加えた電界の 3 倍の強度に達する

電荷分布の形状によって決まるので，電界の強さ，方向 によってその表面位置は容易にずれることになる。

ジェリウムのような理想的に平な表面ではなく，実際 の結晶表面のように原子による凹凸がある場合には，表 面電界はどのようになるのか？ 量子論からの帰結は 4 章で説明することにして，乙こでは古典論の範囲で見て みる。図 2 加わかるように，半球の形の突起をむった 表面に一様電界 $F_{0}$ をかけると, 半球加ら遠く離れた地 点では電界強度はほぼ $F_{0}$ に等しいが, 半球に近づくと 増加し，半球直上では $3 F_{0}$ になってしまう。

さて，ジェリウムでもなく古典的半球突起でもない実 際の結晶表面で電界分布はどうなっているのだろうか? 答は 4 章で見るととにしよう。

\section{3. シミュレーションの方法}

結晶の安定構造は，原子の配置と電子状態がともにそ の系の全エネルギーを最小にするときに得られる。電界 をかけた場合，系を安定化させるために電荷分布が変形 するととあに原子配置すずれる。いわゆる表面緩和現象 が期待される。この構造最適化を行う最む良い方法とし て第一原理分子動力学法 (以下, FPMD と呼ぶことに する）がある。その数学の詳細は文献6)を見ていただく ことにして，簡単にその概念を紹介する。

図3を見ていただきたい。系の全エネルギー $E$ は電 子状態 $\phi$ と原子配置 $R$ で決まる。したがって，エネル ギー曲面 $E(\phi, R)$ の最低位置が結晶の安定構造に対応 


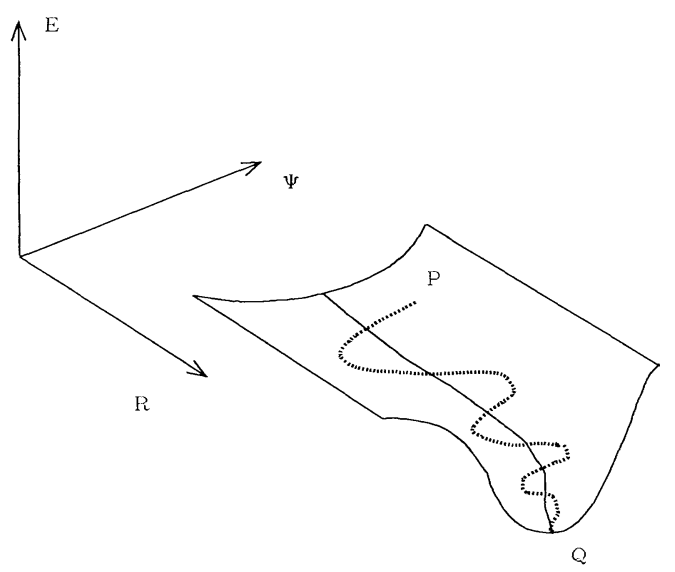

図 3 第一原理分子動力学法の概念図 エネルギー曲面 $E$ は電子状態 $\phi$ と原子配置 $R$ で 決まる。たとえば初期状態 $P$ 加ら出発し, 運動方 程式を解いてエネルギー最小值を与える安定状態 $Q$ に向汃う

する。計算上の初期位置が $P$ であるとき, 摩擦項を含 むニュートンの運動方程式にしたがって “仮想粒子”が $E$ というポテンシャル曲面に沿って安定位置 $Q$ 亿到達 する。乙れが最適化のプロセスである。乙てで，伝統的 な (古典) 分子動力学法との違いは, 原子間ポテンシャ ルが逐次そのときの電子状態によって決定されていくと いう点にある。乙れが “第一原理” の意味するとてろで あある。今回の計算では電界と電子・原子との相互作用 がエネルギー $E$ に付け加わることになる。

\section{4. 強電界下での $\mathrm{Si}(100)$ 表面}

Si (100) 表面は二量体（ダイマー）を基本単位として $(2 \times 1), \mathrm{p}(2 \times 2), \mathrm{c}(4 \times 2)$ などの構造をとるが，乙こ では最む基本的な $(2 \times 1)$ 構造化ついての電界効果 9,10$)$ を見るととにする。

\section{1 表面原子, 電荷分布之電界}

まず，電界の方向を変えるととにより表面原子配置が ぞうずれるかを見てみる。図4 亿は Si (100) 表面のダイ マー近くの原子が示されている。正, 負の電界が加わっ た場合のずれた原子位置が，図 4(a)，4(b) 亿それぞ れ実線で描加れている。全体として原子位置の動きが小 さいのは計算上使われた系が小さいという理由からで, 実際にあう少し大きいと予想される。それでも電界の方 向による特徵的な変化がわかる。正電界(図 $4(\mathrm{a})$ ) の場 合は真空に突出した原子Uが大きく動き，他の原子には ほとんど変化が見られない。一方, 負電界（図 4(b ) ) の場合はほとんどの表面原子は動く。とのような特徵は 加えた電界が強い（土1.8V/Å）という理由のほかにダ
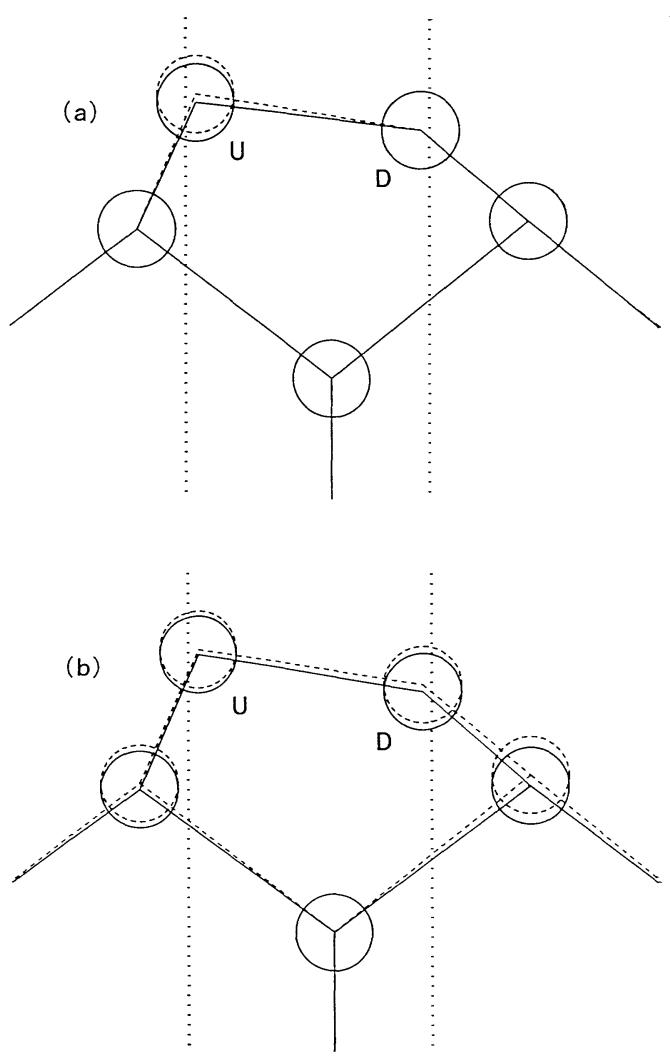

図 4 表面原子緩和

破線の丸が電界のかかっていないときの原子配置 で，実線の丸が電界のかかったときの原子配置

(a) 正電界 $(1.8 \mathrm{~V} / \AA)$ 咖かったとき

(b)負電界 $(-1.8 \mathrm{~V} / \AA)$ 加かかったとき，縦の 2 本の点線は図 5 を描くときの位置

イマーのように比較的強く束縛されている二原子の構造 が原因となっているのかむしれない。ての点に関しての 正確な物理的解釈はまだ得られていない。

つぎに電荷分布のずれを正電界の場合に見てみよう。 図 5 にダイマーのU原子とD原子近傍のふるまいを示し た。表面電荷が侵食されていく様子がU，Dどちらの原 子近くにあ見られる。乙れは正電界が表面電子に反発力 を与え，内部へ電子を押しやった結果で，ジェリウム表 面に挑いてあ見られた現象であった。しかし，図 5(a) と $5(\mathrm{~b})$ の違いからあわかるように, 突出原子U付近で の電荷分布の変化が原子 $\mathrm{D}$ 付近に比へ顕著になるという 点はジェリウムモデルからは当然推測できなかった。

傾いたダイマー (非対称ダイマーという) 亿電界をか けるととにより，原子UはDの位置に近づき(図 4(a))， さらに電界分布の形状（図 $5(a) ，(b)$ の実線）がUと $\mathrm{D}$ 付近で似てきて,対称ダイマーに近づく様子が見える。 つぎに局所電界強度の分布を見てみよう。外から 1.8 

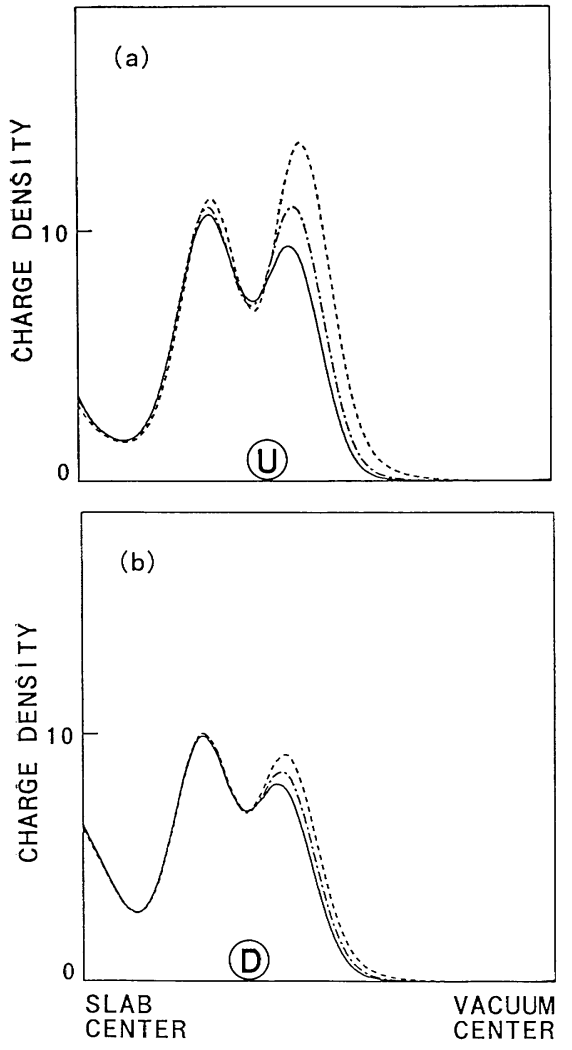

図 5 正電界中の表面電荷分布

破線，一点鎖線，実線がそれぞれ， $F_{0}=0,1.2$, $1.8(\mathrm{~V} / \AA)$ の場合

(a)図 4 の左側の点線上（U原子上）での電荷分布

(b)図 4 の右側の点線上（D原子上）での電荷分布

$\mathrm{V} / \AA ̊$ の電界を加えた場合, 表面近くでその電界強度が 場所によってどう変化しているかを見たのが，図6であ る。原子UとDの位置をての面に射影して書いてある。 強度は突出原子Uの位置で最む大きく, 表面原子から遠 い位置 (図の左右端) ではほとんぞ印加した電界強度に 等しい。原子U近傍ではおよそ $30 \%$ 增大していた。乙 の現象はジェリウム表面（図 1(a)）からはまったく想 像できず，また古典論（図2）の結果である 3 倍とも大 きくかけはなれていた。このことは, 第一原理的解析の 重要性を意味する。

\section{2 電界蒸発}

強い正電界を表面にかけると, いくつかの表面原子は 正イオンとなって真空中に飛び出てくる。乙れは電界蒸 発といわれる現象で FIM によって実験的に確かめられ てきている。いままでは蒸発機構の説明は経験的に導入 された電界ポテンシャルによって現象論に立脚してなさ れてきた。そてで, 今回の第一原理的解析にもとづいて 得られた電界蒸発の発生条件について見てみる。 u

D

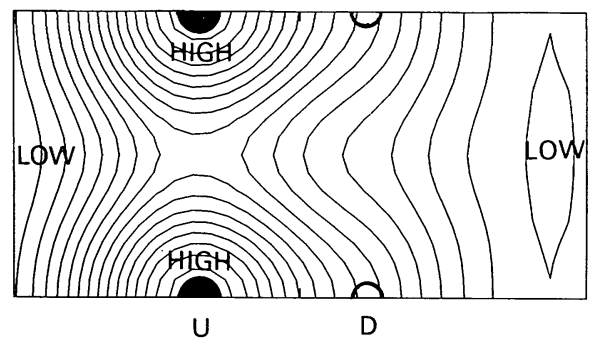

図 6 表面近くの局所電界

U 原子から $2.5 \AA$ 真空側へ離れた面における外部 電界強度。突出原子U直上では $30 \%$ ほど増大して いる

強電界 $F_{0}$ (数 $\mathrm{V} / \AA$ ) 下での表面原子は熱振動などの 原因で表面上の安定位置から真空側へ移動し, ある特徴 的な距離 $X_{c}$ はなれると，原子上の電子が表面側にトン ネルしてゆく確率が急に增大し, 原子は正に帯電しイオ ンとなって蒸発してゆく。その臨界距離 $X_{c}$ は加えた電 界の強度 $F_{0}$ によって変化する。図 7 に $X_{c}-F_{0}$ の関 係をつぎの三つの場合に分けて示す。

(a) 正電界下で 1 個の原子（正イオン）が蒸発する としたとき。

（b）正電界下で 2 個の原子（正イオンダイマー）が 同時に蒸発するとしたとき。

（c）負電界下で 1 個の原子（負イオン）が蒸発する としたとき。

それぞれの曲線の右上側の電界強度あるいは原子位置 で蒸発可能である。したがって，蒸発しやすい順序に並

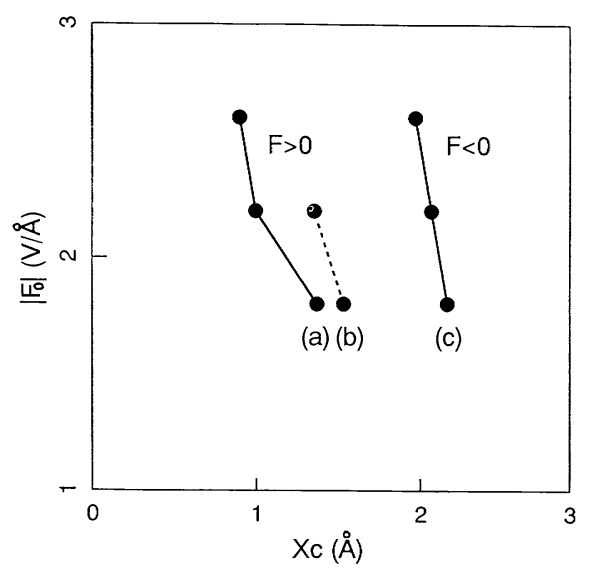

図 7 電界蒸発の条件

原子が表面の安定位置から $X_{c}$ 離れたとき, 蒸発す るための必要な電界強度 $F_{0}$
(a) 正電界下の単原子蒸発
(b) 正電界下のダイマー蒸発
(c)負電界下の単原子蒸発 
べると，正イオン>正イオンダイマー》負イオン，とい うことになる。FIM において Si 負イオン蒸発が観測さ れていないという実験事実を裏づけている。

最近，小林ら ${ }^{111}$ にって報告されたSTM 観察による と，負イオンダイマー蒸発も起こっているようである。 今回の理論結果之従来の FIM の実験加ら, STM の針 との相互作用によって負イオンが蒸発しやすくなってい ると考えるのが自然である。しかし今のとてろ，STM 針の役割を電界蒸発機構に取り込んだ第一原理的電子論 はない。乙れからの課題である。

\section{5. おわりに}

強電界が固体表面に印加されたとき何が起こるかを， 特に $\mathrm{Si}(100)$ 表面を例に挙げて見てきた。電界は表面電 荷分布を変形し電子状態を変え，また電子自身を表面内 部から真空へ放出するてとあある。電子に対してだけで なく，電界は表面原子緩和，再構成を引き起乙し，原子 の表面束縛ポテンシャルむ変え，ときには原子を表面か ら引き剥がすととあある。乙れらの表面過程の機構を原 子スケールで理解するためには，電界の果たす役割を従 来の現象論によって考えるだけでは不十分で, 第一原理 的電子論の枠組みの中で調べ直さなりればならない。さ らに，そうして得られた電界効果に対する定量的理解に よって，表面の新物性を予測するてとができ，電界を積
極的に用いた物質設計が可能になると考えられる。電界 は古くて新しい道具ということになるのであろうか？

\section{文献}

1) D. M. Eigler and E. K. Schweizer: Nature 344, 524 (1990).

2) I.-W. Lyo and P. Avouris: Science 253, 173 (1991).

3) D. M. Eigler, C. P. Lutz and W.E. Rudge: Nature 352, 600 (1991).

4) T. T. Tsong: "Atom-Probe Field Ion Microscopy" (Cambridge University Press, Cambridge, 1990).

5）渡辺一之, H. J. Kreuzer：応用物理 59,175 (1990).

6）小ロ多美夫，佐々木泰造：固体物理 25,857 (1990).

7) N. D. Lang: "Solid State Physics" 28, H. Hhrenreich, F. Seitz and D. Turnbull, (eds.) (Academic Press, 1973) p. 225

8) K. Watanabe, S. H. Payne and H. J. Kreuzer: Surf. Sci. 202, 521 (1988).

9) K. Watanabe and K. Watanabe: J. Phys. Soc. Jpn. 61, 419 (1992).

10) K. Watanabe and T. Satoh: to appear in Surf. Sci.

11）小林中, F. Grey, 青野正和：日本物理学会 1992 年秋の分科会 $28 \mathrm{a}-\mathrm{Y}-8$. 